セトン $5 \mathrm{~m} l$ を採取して各温度で滴定した結果は Table IV に示すように $15^{\circ} \mathrm{C}$ 以下でよいことを知った。

Table IV 滴定温度の影響

\begin{tabular}{ccc}
\hline \hline 滴定温度 $\left({ }^{\circ} \mathrm{C}\right)$ & 水分湖定值 $(\mathrm{mg})$ & 妨害反応の有無 \\
\hline 30 & 12.53 & 有 \\
25 & 12.25 & $\prime \prime$ \\
20 & 12.23 & $\prime$ \\
15 & 12.11 & 無 \\
10 & 12.08 & $" \prime$ \\
\hline
\end{tabular}

以上の結果から, 著者らはアセトン中の水分定量条件 をつぎのように決定した.

試料溶媒 : プロピレングリコール:ピリシシン = $1: 1$ の 混合溶媒 $30 \mathrm{ml}$

滴定温度 : $10 \sim 15^{\circ} \mathrm{C}$

試料採取量: $20 \mathrm{ml}$ 以下

試料含水量 : $50 \mathrm{~m} l$ 以下

\section{$3 \cdot 3$ 正確度の検討}

決定した定量条件で，既知量の水を含むアセトンの水 分を定量した結果, Table V に示すように $1 \%$ 以内の 誤差範囲で一致した。

Table $\mathrm{V}$ 正確度の検討

\begin{tabular}{ccccc}
\hline $\begin{array}{c}\text { 試 料 } \\
\text { No. }\end{array}$ & $\begin{array}{c}\text { 採取量 } \\
(\mathrm{m})\end{array}$ & $\begin{array}{c}\text { 理論含水量 } \\
(\mathrm{mg})\end{array}$ & $\begin{array}{c}\text { 水分即定值 } \\
(\mathrm{mg})\end{array}$ & $\begin{array}{c}\text { 誤 差 } \\
(\mathrm{mg})\end{array}$ \\
\hline 1 & 5 & 5.26 & 5.31 & +0.05 \\
2 & 5 & 20.15 & 20.08 & -0.07 \\
3 & 5 & 35.05 & 35.23 & +0.18 \\
4 & 5 & 50.13 & 49.82 & -0.31 \\
\hline
\end{tabular}

\section{4 そのほかのケトン類の水分定量}

プロピレングリコール：ピリジン =1: 1 の混合溶媒 $30 \mathrm{~m} l$ に, 各種ケトン類を一定量ずつ採取して連続的に 滴定した結果, Table VIに示すようにメチルエチルケ トン，アセトフェノンは再現性のある值を得たが，シク

Table VI 各種ケトン類の水分定量

\begin{tabular}{|c|c|c|}
\hline 試料種 別 & 試料採取量 $\dagger(\mathrm{m} l)$ & 水分測定值 (mg) \\
\hline メチルエチルケトン & $\begin{array}{r}5 \\
5 \\
10\end{array}$ & $\begin{array}{r}8.91 \\
9.00 \\
17.80\end{array}$ \\
\hline アセトフェノン & $\begin{array}{l}2 \\
3 \\
5\end{array}$ & $\begin{array}{l}26.80 \\
40.24 \\
66.84\end{array}$ \\
\hline シクロヘキサノン & $\begin{array}{r}5 \\
5 \\
10\end{array}$ & $\begin{array}{l}3.42 \\
3.42 \\
6.20\end{array}$ \\
\hline
\end{tabular}

$\dagger$ 同一淩媒に武料を連続的に採取して滴定した.
ロヘキサノンは採取量 $20 \mathrm{~m} l$ になると水と $\mathrm{KF}$ 試薬の反 応速度が抑制され，測定值に負の詔差を認めた。

\section{文献}

1) K. Fischer, F. Karl : Angew. Chem., 48, 394 (1935).

2) J. Mitchell, D. M. Smith : “Aquametry”, p. 151 (1948), (Interscience Publishers Inc., New York).

3) E. D. Peters, J. L. Tungnickel : Anal. Chem., 27, 450 (1955).

4) G. Wernimont, F. J. Hopkinson : Ind. Eng. Chem., Anal. Ed., 15, 272 (1943).

5）三菱化成工業株式会社：“カールフィッシャ一試 薬 SS", パンフレット.テクニカルサービス No. 12, p. 2 (1962).

（昭和 38 年 5 月 18 日受理）

\section{ペン記録式ポーラログラフ用 精密加電圧装置の自作}

中村周, 平田 正*

1 はしがき

現在のペン記録式ポーラログラフは定量分析が主で， 定性分析すなわち半波電位の精度は十分でないようであ る. 一般にこの半波電位の精度を左右するものには主と して次のような原因が考えられる.

i ) 水銀池陽極では電解中の電位の变動

ii ）外部陽極使用のときはとの電位の確度と寒天ブリ ッジの抵抗

iii）溶液の抵抗

iv）記録計の追従性

v) ダンピング回路

vi）加電圧ポテンシォメーターの精度

vii）記録計機構とポテンシォメーター機構の同期

viii) その他

これらについてはそれぞれ対策が考えられているが， ここではvi）とvii)について検討してみることにした。 ペン記録式に用いられている加電圧ポテンシォメーター は約 $200 \Omega, 1$ 回転式(角度約 $330^{\circ}$ ) の巻線抵抗が用いら れ，接触子がしゅう動する長さはおよそ $32 \mathrm{~cm}$ であ. この場合, 任意の電圧設定精度は $5 \mathrm{~m} \mathrm{~V}(0 \sim 2.0 \mathrm{~V}$ スパ ン）にも及ぶ誤差が見られることがある・また，記録紙 駆動とポテンシォメーター駆動が単一のモーターであっ

* 九州大学教養部化学教室 
ても，また別個のモーターであっても，加電庄目盛と記 録紙の電圧目盛との一致はむずかしく, 0 2.0V スパン の場合, 1.5〜2.0V 付近ではかなりのずれを示すことが ある.それでこれらの点の改善を試みることにした。

\section{2 試作装置の概要}

\section{$2 \cdot 1$ 改良の主眼点}

i ）任意の点における加電圧の設定精度は $1 \mathrm{mV}$ 以下 に保ち, 電源および電圧チェックはスイッチで切換えて 本体と共用できること.

ii）記録紙に写真式と同じくポテンシォメーターに同 期して電圧目盛を記入するようにする.

iii）スパン電圧の正負を逆転可能にする.

\section{$2 \cdot 2$ 使用したおもな部品}

i ) 加電圧ポテンシォメーター：栄通信工業K.K.の ヘリカロームS 46 HD-20 を用いた. 両端スイッチ付き でシャフト両出, 抵抗值は $200 \Omega$ である. 直径 $30 \mathrm{~mm}$ のベークライトボビンに約 $180 \mathrm{~cm}$ の巻線抵抗を 20 回 巻きつけた複巻の抵抗体の上を特殊合金の接触子 $(\phi 1.6$ $\mathrm{mm}$, 長さ $3 \mathrm{~mm}$ ) がしゅう動していく. ダイアルは専 用のマルチダイアル MA 20-100で円周を100等分した 目盛があり，回転数も同時に示すことができる.

ii) ポテンシォメーター駆動用モーター：定速回転を することと逆回転できることが必要である・レバーシブ ルインダクションモーターを用いた. 回転数は 1350 回/ 分 $(14 \mathrm{~W})$ であったので減速ギャへッドで約 30 秒で 1 回 転になるようにした。

iii）電圧目盛記入装置: 柳本製作所のガルバレコーダ 一の電圧記入装置を用い，これを作動させる接点として マイクロスイッチを使った.

\section{$2 \cdot 3$ 自作の要点}

著者らが改造したのは柳本 PB-4 型であるが，ほか の型あるいは他社の製品でも同様に行なえるはずであ る.まずポーラログラフ本体にコネクター,スイッチを 取付けるとともに Fig. 1 の本体部のように配線を変え る. ×印の箇所は切断しなければならない. 記録紙の右 または左側に電圧目盛がはいるように金属ペンを取付 け，それを作動させるプランジャ（電磁石）を適当な籄 所に設置する.ただしセレン整流器, トランスなどは本 体あるいは本装置どちらに設けてもよい. 本装置のシャ ーシはしっかりしたものがよく，自作するときには 1 $\mathrm{mm}$ 以上の厚さの鉄板を用いる. モーターとポテンシ ホメーターとの接続はこれらを直結すると,ポーラログ

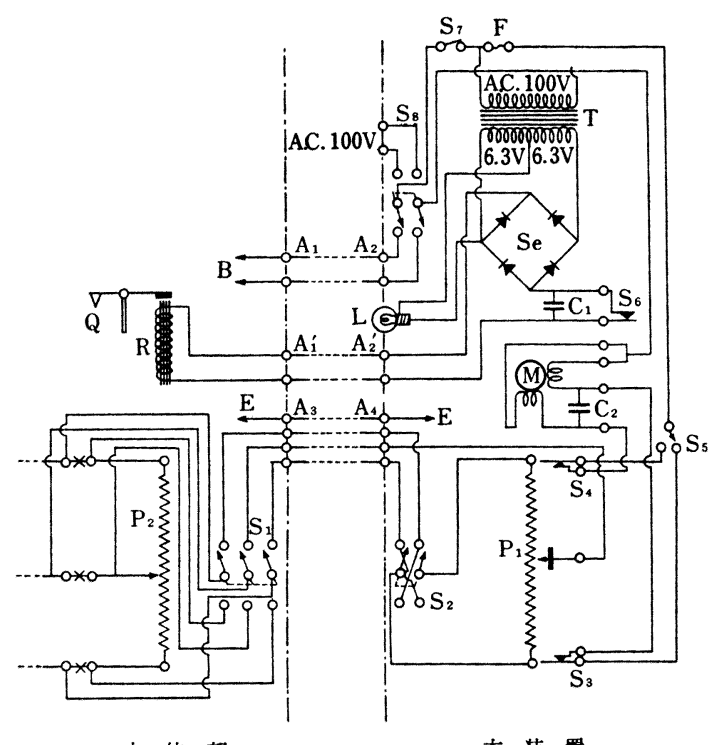

本 体部

Fig. 1 配 線 図

$\mathrm{A}_{1} \sim \mathrm{A}_{4}, \mathrm{~A}_{1^{\prime}}, \mathrm{A}_{2}{ }^{\prime}$ : メタルコネクター

$\mathrm{B}$ : 記録紙駆動モー夕一端子へ $\quad \mathrm{C}_{1}: 10 \mu \mathrm{F}$

$\mathrm{C}_{2}: 2 \mu \mathrm{F} \quad \mathrm{E}:$ アース $\mathrm{F}:$ ヒューズ

$\mathrm{L}$ : パイロットランフ $\mathrm{M}:$ レバーシブルモーター

$\mathrm{P}_{1}: 20$ 回転ポテンシォメーター

$\mathrm{P}_{2}$ : 本体加電圧ポテンシォメーター $\quad \mathrm{Q}:$ 金属ペン

$\mathrm{R}:$ プランジャ $\mathrm{S}_{1}$ : 本体, 陚作莣置切換スイッチ

$\mathrm{S}_{2}$ : スパン電王正負逆転スイッチ

$\mathrm{S}_{3}, \mathrm{~S}_{4}$ : ポテンシォメーター付属スイッチ

$\mathrm{S}_{5}$ : モーター逆転スイッチ $\mathrm{S}_{6}$ : マイクロスイッチ

$\mathrm{S}_{7}:$ 電源スイッチ $\mathrm{S}_{8}:$ 電源切換スイッチ

$\mathrm{Se}:$ セレン整流器 $\mathrm{T}:$ ヒータートランス $12.6 \mathrm{~V}$

$x:$ 切断篭所

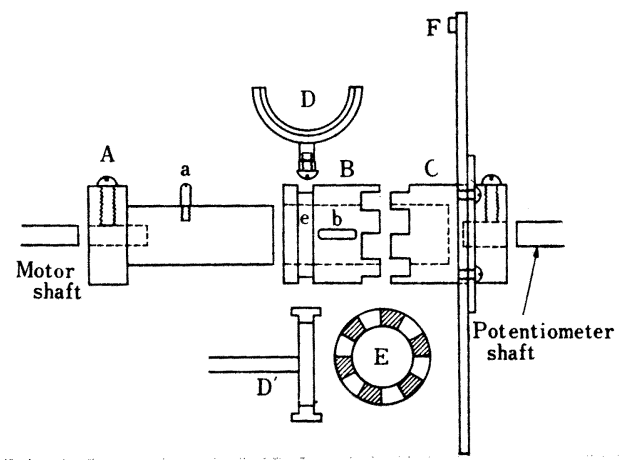

Fig. 2 クラッチ部分の機構

操作法：モーターシャフトルAをはめ，aをはずしてB をAに入れ，bの穴を通してaをつける，BとCをかみ 合わせ，Cにポテンシォメーターシャフトをはめる，B のみぞ $\mathrm{e}$ にDをはめ、レバーでDを前後すれば $\mathrm{B} る$ 前後 し，Cとのかみ合わせをはずしたり入れたりするととが できる.とれによりモーターの回転がポテンシォえ゙ータ 一に伝わり，あるいは切れる。

$\mathrm{D}^{\prime}$ : Dを上から見た所

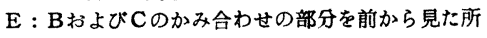


ラムを中途から記録する場合などに加電圧を任意に設定 することができなくなるから, クラッチを作り手動とモ ーター駆動とをレバーで切換えるようにする．Fig. 2 はそのクラッチの構造を示す. 電圧目盛を入れるために ポテンシォメーター 1 回転ごとにマイクロスイッチを作 動させるには，ポテンシォメーターのシャフトに黄銅製 円盤を直結し, この円盤に突起を 1 個設けてポテンシお メーターダイアルが 0 を示すとき，ちょうどその突起が マイクロスイッチを押すようにする．この円盤とクラッ チ部分は黄銅で作るが旋盤の心得のある人なら容易に自 作できる. 加電圧ポテンシォメーターは接触子が両端に 達したとき， $\mathrm{S}_{3}$ または $\mathrm{S}_{4}$ が働いてモーターが自動的に 止まるように配線し, このときは $S_{5}$ で逆転させること ができる.

\section{3 検討}

\section{$3 \cdot 1$ 本装睥の精度}

加電圧ポテンシォメーターの両端に $1.0 \mathrm{~V}$ を加えて おき, 1 回転ごとの電圧を測定しその繰返しの精度を従 来の 1 回転式の ポテンシォメーターと比較したものを

Table I ポテンシォメーターの精度 †

\begin{tabular}{ccc}
\hline \multirow{2}{*}{ ダイアルの目盛 } & \multicolumn{2}{c}{ 電圧の読みの差 $(\mathrm{mV})$} \\
\cline { 2 - 3 } & 1 回転式 & 本 峦 置 \\
\hline 0 & 0.0 & 0.0 \\
4 & 2.1 & 0.2 \\
8 & 2.0 & 0.2 \\
12 & 1.7 & 0.2 \\
14 & 2.8 & 0.2 \\
16 & 2.2 & 0.4 \\
\hline
\end{tabular}

† 測定の一部だけを示す.
Table I に示す. 電圧は島津 3P 型電位差計で測定 し，読みの差の最大值を示した。

Table I によれば加電圧の精度が向上したことがわ かる。

\section{$3 \cdot 2$ その他の長所と欠点}

本装置により従来記録開始時行なっていた記録ぺンを 記録紙の目盛に合わせる操作は不必要となり，随時記録 を開始できるとともに最後まで加電圧目盛がずれること なく正確に記録される.こうして半波電位の精度を必要 とする場合にもペン記録式を十分使用できるようになっ た。

更に精度をあげるには逆転装置を用い $-2.0 \mathrm{~V}$ 上り 0 V方向にスカニングを行なって記録し，その半波電位の 平均をとれば 1-iv), v) の欠点がある程度避けられる。 これ以上の精度を望むときは検流計を用い手動で行なう ほかはない。

欠点としては記録紙駆動モーター, または本装置モー ターの回転中における回転数の変化による目盛間隔の不 同が考えられるが，この誤差は短時間におけるモーター の極端な回転数の変化がない限り無視できるであろう. またこのポテンシォメーターは $-2.0 \mathrm{~V}$ まで回転した のち接触子を $0 \mathrm{~V}$ にもどすにはダイアルをいちいち 20 回転させ致ばならないが, これはスパン電圧の正負とモ 一ターの回転を逆転させれば，そのまま次のポーラログ ラムを記録することができてかえって便利である。な お，本装置の製作に要した費用はおよそ 2 万円程度であ った。

（昭和 38 年 4 月 16 日受理） 